\title{
低レイノルズ数で作動する回転翼による小型アクチュエータ*1 Small Actuator with Propellers Acting under Low Reynolds Numbers
}

\author{
得竹浩*2 $\cdot$ 砂 田茂 ${ }^{2} \cdot$ 藤 永 仁*2 \\ Hiroshi ToKutake, Shigeru SunAda and Jin Fujinaga
}

Key Words : Actuator, Low Reynolds Number, Propeller

\begin{abstract}
The characteristics of a small actuator with propellers have been studied. The generated force increases as the rotational speed of the propellers and the viscosity of the liquid inside the actuator increase. This can be predicted by a simple analysis using the characteristics of wings at the Reynolds numbers where they operate. The understanding of wing characteristics at low Reynolds numbers, which has recently become important for designing a MAV (Micro Air Vehicle), can contribute to developing a small fluid machinery such as this small actuator with propellers.
\end{abstract}

\section{1. は じめに}

航空機や車両など多くのビークルにおいて運動制御装置 が実用化されている，乥れらの制御装置では，操縦桿や八 ンドルなどの操緃感覚が重要となる . 本研究では, 人の操 舵を補助する用途を想定した小型のアクチュエータ ${ }^{1)}$ を開 発した . 任意の力を発生させるとともに , 外力に対しては ダンパとして働く装置である.アクチュエータが発生する 力より大きな外力を加えると, 兴の外力に従ってアクチュ エータは動き，弚の速度に比例した反力を発生する．この 装置を利用すれば操舵補助に加えて減衰力からなるフィー ルシステムを構成することが可能である．本アクチュエー タは自転車の操舵補助装置に適用された実績がある(たと えば文献 2)）。

また，近年マイクロエアービークルの開発が盛んになっ てきており, $10^{5} \sim 10^{6}$ のレイノルズ数下での翼特性の研究 か数多く行われている3).さらに低い $10^{4}$ 以下のレイノル ズ数での翼特性は, 主に昆虫の飛行の解明のために調べら れてきたが, 今後，航空機の小型化がさらに進むと，弚の 開発に利用できる可能性がある．また，小型の流体機器で 回転翼が用いられる場合， $10^{4}$ 以下のレイノルズ数で作動 する場合がある . 本アクチュエータはプロペラを用いた油 圧機器であるが， このプロペラは 50〜 $2 \times 10^{3}$ のレイノル ズ数で作動する．本アクチュエータは，このような低いレ イノルズ数で作動するプロペラによって力を発生すること による特性を有している．本稿では，プロペラが低レイノ ルズ数で作動するために発現する，本アクチュエータの特 性について述べる。

本稿は新しいアクチュエータについて述べたものである

*1 (C) 2006 日本航空宇宙学会

平成 17 年 9 月 16 日, 第 37 回流体力学講演会において発表. 平 成 17 年 9 月 1 日原稿受理

*2 大阪府立大学大学院工学研究科航空宇宙海洋系専攻航空宇宙工学 分野
が，操縦補助に適することや光の性能が翼特性によること など航空宇宙工学分野との関連は深い . 総合工学である航 空宇宙工学の知見を他の分野に広く活用した 1 例であると 言える .

\section{2. 開発したアクチュエータ}

開発したアクチュエータは， $X=100 \mathrm{~mm}, Y=60 \mathrm{~mm}$ ， 奥行 $Z=30 \mathrm{~mm}$ の直方体のケースと光の外部にある DC モータ (マブチモーター (株) 製，RS-540SH) とからな る.第 1 図に示すように , ケースの中は内径 $d=20 \mathrm{~mm}$ の 円形断面の流路から形成されている . 流路内には流体か満 たされ，さらにプロペラ, 移動板が置かれている.プロペ ラは直径 $d_{\mathrm{p}}$ の回転軸て接続する DC モータによって駆動さ れる.プロペラによって駆動される流路内の流体が, 直径 $a=0.018 \mathrm{~m}$ または $0.0196 \mathrm{~m}$ の移動板に力を及ぼす . 移動 板は直径 $d_{\mathrm{m}}$ の軸に連結し，軸はケースを貫通し，軸の一 端，点 A で外部に力を作用することができる .

プロペラは, プロペラ $\mathrm{A}$ (半径 $R=9.6 \mathrm{~mm}$ ，コード長 $c=6.0 \mathrm{~mm}$ ) とプロペラ B (半径 $R=9.9 \mathrm{~mm}$, コード長 $c=11.7 \mathrm{~mm}$ ) の 2 種類を用意し (第 2 図)，プロペラ段数 は $N=4,6,8$ とした .どのプロペラのピッチ角も, 翼取 り付け部で 0 度, 翼端で 30 度で, 光の間は線形に変化す る.本アクチュエータは DC モータを正・逆回転させるこ とによって，第 1 図に示す $x,-x$ の両方向に力を発生可 能であるが，両方向の特性を等しくするために，プロペラ の断面形状は，対称翼 (平板翼) としている.また，同理 由によって，各段においてプロペラピッチ角を変えること をせず，同一形状のプロペラを使用している．なお，アク チュエータの形状に関する諸元を第 1 表にまとめる .

\section{3. 性能試験方法}

3.1 アクチュエータ出力測定 上記のように,プロペラ サイズ, 段数, 移動板直径をパラメータとし, プロペラ回転 
第 1 表 アクチュエータの諸元

\begin{tabular}{lcl}
\hline \multicolumn{1}{c}{ Items } & Abbreviation & \multicolumn{1}{c}{ Values } \\
\hline Diameter of moving plate & $a$ & $18,19.6 \mathrm{~mm}$ \\
Thickness of moving plate & $t_{\mathrm{m}}$ & $2 \mathrm{~mm}$ \\
Diameter of a moving bar & $d_{\mathrm{m}}$ & $6 \mathrm{~mm}$ \\
Radius of propeller & $R$ & $9.6 \mathrm{~mm}$ (propeller A) \\
& & $9.9 \mathrm{~mm}$ (propeller B) \\
Chord length of propeller & $c$ & $6 \mathrm{~mm}$ (propeller A) \\
& & $11.7 \mathrm{~mm}$ (propeller B) \\
Thickness of propeller & $t_{\mathrm{p}}$ & $0.5 \mathrm{~mm}$ (propeller A) \\
& & $0.8 \mathrm{~mm}$ (propeller B) \\
Number of propeller stages & $N$ & $4,6,8$ \\
Diameter of propeller hub & $d_{\mathrm{h}}$ & $6 \mathrm{~mm}$ (propeller A) \\
& & $7 \mathrm{~mm}$ (propeller B) \\
Diameter of rotational axis of propeller & $d_{\mathrm{p}}$ & $3 \mathrm{~mm}$ \\
\hline
\end{tabular}

第 2 表 作動流体の諸元

\begin{tabular}{llll}
\hline \multicolumn{1}{c}{ Liquid } & \multicolumn{1}{c}{ Viscosity, $\eta$} & Density, $\rho$ & \multicolumn{1}{c}{ Brand name (Company) } \\
\hline Suspension oil 1 & $0.02 \mathrm{~N} \cdot \mathrm{s} / \mathrm{m}^{2}$ & $763 \mathrm{~kg} / \mathrm{m}^{3}$ & fork oil 5WT (Rock Shocx) \\
Suspension oil 2 & $0.075 \mathrm{~N} \cdot \mathrm{s} / \mathrm{m}^{2}$ & $845 \mathrm{~kg} / \mathrm{m}^{3}$ & fork oil 10WT (Rock Shocx) \\
Silicon oil 1 & $0.50 \mathrm{~N} \cdot \mathrm{s} / \mathrm{m}^{2}$ & $880 \mathrm{~kg} / \mathrm{m}^{3}$ & KF-96-500CS (Shin-etsu Chemical) \\
Silicon oil 2 & $1.0 \mathrm{~N} \cdot \mathrm{s} / \mathrm{m}^{2}$ & $897 \mathrm{~kg} / \mathrm{m}^{3}$ & KF-96-1000CS (Shin-etsu Chemical) \\
\hline
\end{tabular}

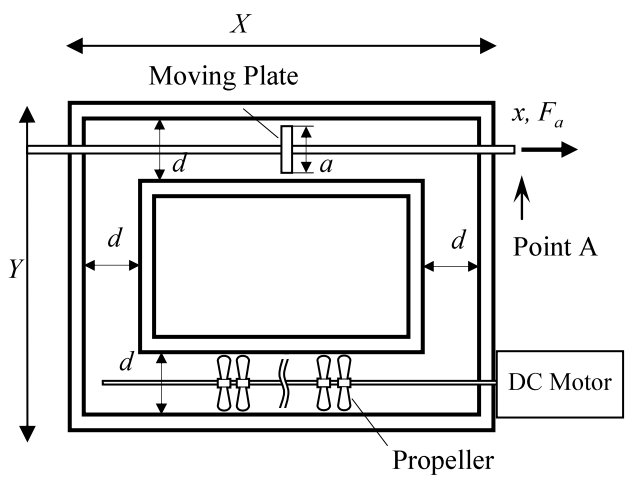

第 1 図 開発したアクチュエータ

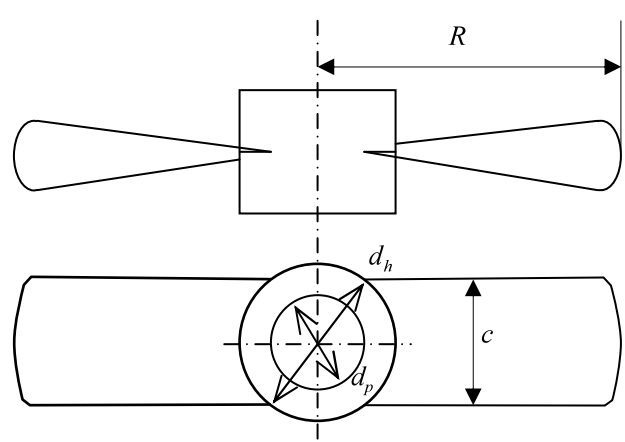

第 2 図 アクチュエータで用いられるプロペラ

数とアクチュエータの出力 $F_{\mathrm{a}}$ との関係を測定した . また 本性能試験においては，第 2 表に示す流体で流路を満たし た . 回転数の測定には非接触型のディジタル・タコメータ ( (株) 小野測器製, HT-5100) を, 力の測定には CPU ゲー ジ (アイコーエンジニアリング (株) 製, MODEL-RX-1) を使用した .この測定は, 直動軸が動かず, 点 A の変位を 0 として行われたものである .
3.2 アクチュエータ減衰力測定 本アクチュエータの 出力軸に外力を加えた場合, アクチュエータの変位が発生 (点 A が移動) しながら，出力軸には抵抗力が働くことに なる.この抵抗力を測定するために, 点 $\mathrm{A}$ を $-x$ 方向に 一定速度 $V$ で移動したときの, 抵抗力 $F_{\mathrm{d}}$ を測定した $V$ はポテンショメータ ((株) ミドリ測器製, GreenPot LP$200 \mathrm{~F}$ ) で, $F_{\mathrm{d}}$ は CPU ゲージ (アイコーエンジニアリング (株) 製，MODEL-RX-1) を用いて測定した .この測定の 際, アクチュエータ内はシリコンオイル $1\left(\eta=0.5 \mathrm{~N} \cdot \mathrm{s} / \mathrm{m}^{2}\right.$, $\left.\rho=880 \mathrm{~kg} / \mathrm{m}^{3}\right)$ で満たされ，4 段のプロペラ B を使 用し，以下のヶースについて測定を行った . (ケース 1) $a=19.6 \mathrm{~mm}$ の作動板を使用し，プロペラを約 $7500 \mathrm{rpm}$ で回転させた場合 (この場合, 点 A の変位が 0 である条 件下で測定されたアクチュエータの発生力 $F_{\mathrm{a}}$ は, 第 6 図 から $8 \mathrm{~N}$ である)，(ケース 2) $a=19.6 \mathrm{~mm}$ の作動板を使 用し, プロペラを回転させずアクチュエータとしての発生 カが $0 \mathrm{~N}$ の場合，(ケース 3) 作動板を取り去り，プロペラ を回転させずアクチュエータとしての発生力が $0 \mathrm{~N}$ の場合， の 3 ケースである .

\section{4. 理 論 解 析}

上記レイノルズ数で作動するプロペラであることを念頭 に ,アクチュエータの発生力の特徵を示す解析式を導く . ま ず, プロペラについて考える．プロペラとケーシング, プ ロペラ段間の干渉を無視し , 本アクチュエータのプロペラ を, 開空間にある $N$ 枚の単独プロペラとすると, プロペラ 全体の発生する推力 $T$ (翼素理論 ${ }^{4)}$ によって以下のように 書ける .

$$
T \propto N \rho R^{3} c \Omega^{2}\left(C_{\mathrm{l}}-C_{\mathrm{d}} \phi\right) \approx N \rho R^{3} c \Omega^{2} C_{\mathrm{l}}
$$

ここで $C_{1}, C_{\mathrm{d}}, \phi$ はプロペラのスパン方向で平均した揚 力係数，抗力係数，誘導迎角であり，幾何迎角が $30^{\circ}$ 以下 
であることから， $\phi<1$ である .また，上記レイノルズ 数領域で迎角が $30^{\circ}$ 以下の場合， $C_{1}>C_{\mathrm{d}^{5}}{ }^{5}$ であるので， $C_{1}-C_{\mathrm{d}} \phi \approx C_{1}$ とした .

一方， $N$ 段のプロペラか開放空間にあり， $N$ 段のプロペ ラを半径 $R$ の 1 枚の作動円盤と考える . 光の際 , プロペラ 全体の発生する推力 $T$ (単純運動量理論 $\left.{ }^{4}\right)$ によって以下の ように書ける.

$$
T \propto \rho R^{2} v^{2}
$$

ここでvは無限後流での誘導速度である.式 (1)，(2)より， $v$ について次式が得られる.

$$
v \propto \sqrt{N R c C_{1}} \Omega
$$

次に , 移動板について考える. 移動板とケーシングの干 渉を無視し，移動板が一樣流速 $v$ の中にあるとする . 移動 板に衝く流体力，すなわちアクチュエータの発生力 $F_{\mathrm{a}}$ は， 以下のように書ける .

$$
F_{\mathrm{a}} \propto \rho v^{2} a^{2} C_{\mathrm{D}}
$$

\section{ここで $C_{\mathrm{D}}$ は移動板の抵抗係数である .}

$R e$ が十分小さいとき，

$$
C_{\mathrm{D}} \propto 1 / R e \propto \frac{\eta}{v a \rho}
$$

である ${ }^{6)}$ ので, 式 $(3) ，(4) ，(5)$ より $F_{\mathrm{a}}$ は次式のように書 ける

$$
F_{\mathrm{a}} \propto \eta \Omega a \sqrt{N R c C_{1}}
$$

\section{5. 結果}

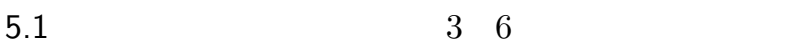
ロペラ $\mathrm{A}, N=4)$ ，(プロペラ A,$N=6)$ ，(プロペラ A , $N=8$ )，(プロペラ B , $N=4$ ) の場合の，プロペラ回転 速度と発生力 $F_{\mathrm{a}}$ との関係を示す. 流体の粘性係数 $\eta$ と移

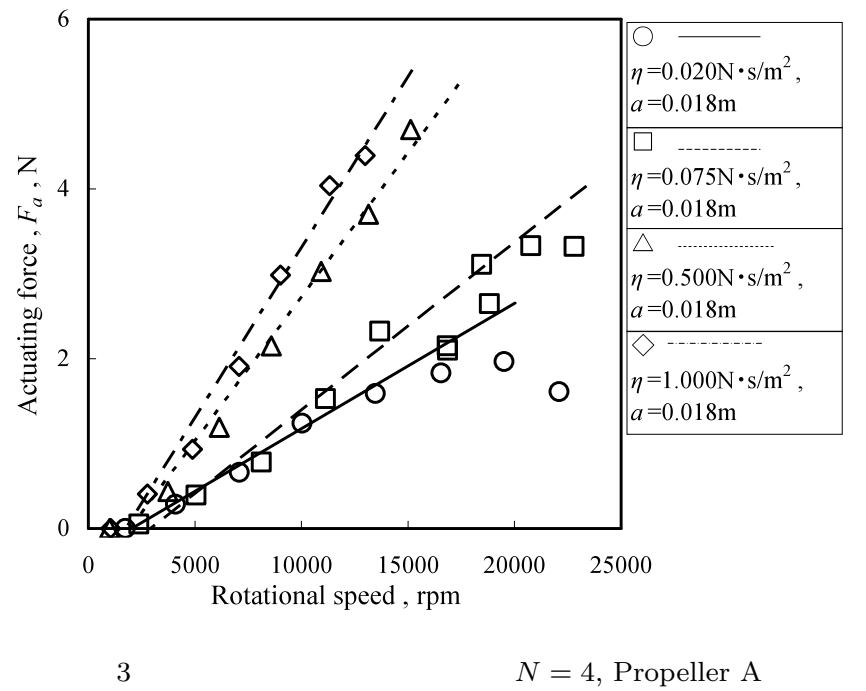

動板の直径 $a$ とがパラメータである.これらの図において シンボル, 各種の線は, 弚れ㢳れ測定結果, 測定結果を線 形近似した結果を表す．また，これらの図から得た $F_{\mathrm{a}}$ と $\eta$ の関係， $F_{\mathrm{a}}$ と $N$ の関係を弚れ光れ，第 7,8 図に示す. なお , プロペラに対する $R e=0.75 R \Omega c \rho / \eta$ は , 回転数 $\Omega$ $=10000 \mathrm{rpm}$ のときを例にとると, $50\left(\eta=1.0 \mathrm{~N} \cdot \mathrm{s} / \mathrm{m}^{2}\right) \sim$

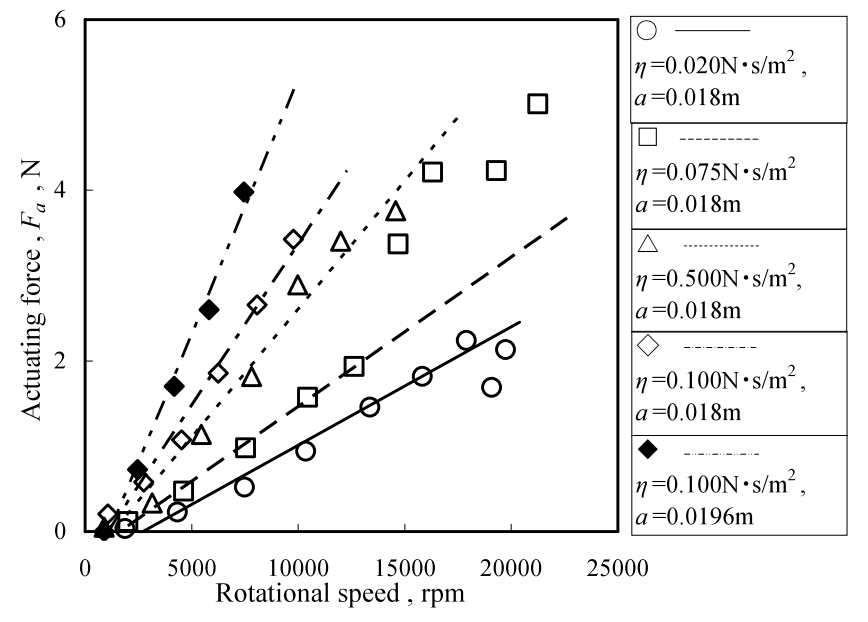

第4図 アクチュエータの発生力 $(N=6$, Propeller A)

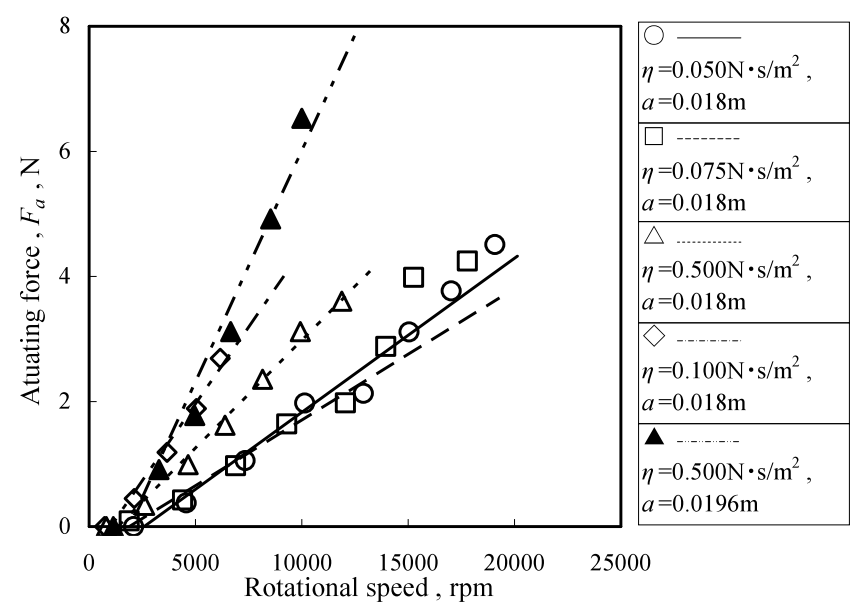

第 5 図 アクチュエータの発生力 $(N=8$, Propeller A)

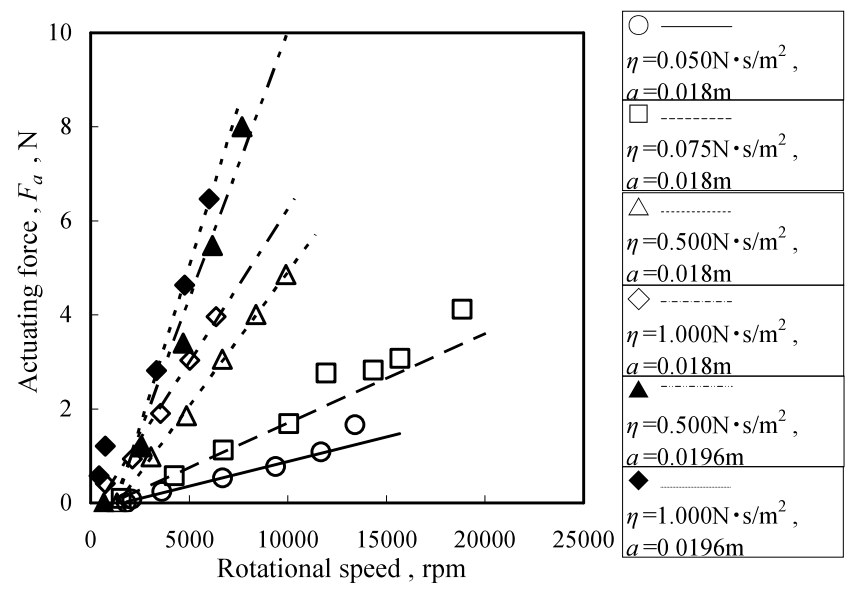

第6図 アクチュエータの発生力 $(N=4$, Propeller B) 


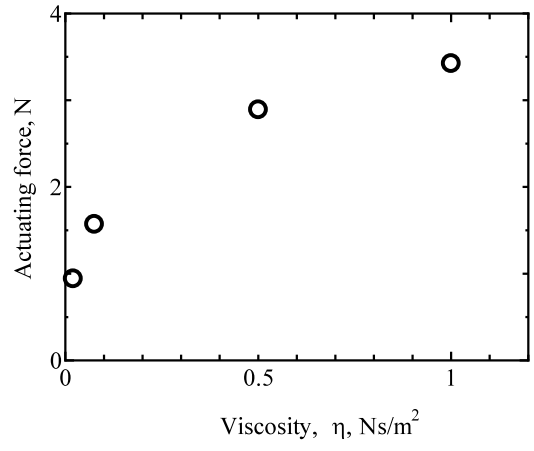

第 7 図 アクチュエータの発生力と粘性係数 (Propeller A, $N=6$, $\Omega=10000 \mathrm{rpm}, a=0.018 \mathrm{~m}$ )

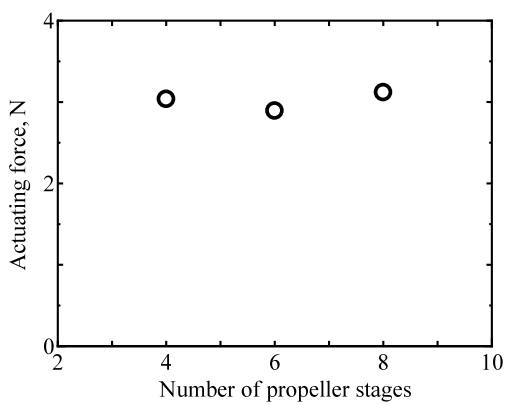

第 8 図 アクチュエータの発生力とプロペラ段数 (Propeller A, $\eta=$ $0.5, \Omega=10000 \mathrm{rpm}, a=0.018 \mathrm{~m}$ )

$2 \times 10^{3}\left(\eta=0.02 \mathrm{~N} \cdot \mathrm{s} / \mathrm{m}^{2}\right)$ 程度である.式 (6) によると， $F_{\mathrm{a}}$ は $\eta, \Omega, a, \sqrt{N}, \sqrt{R}, \sqrt{c}$ に比例することが予想さ れる.この知見に対して，第 $3 \sim 8$ 図より以下のことが言 える。

・第 3 图の $\eta=0.02,0.075 \mathrm{~N} \cdot \mathrm{s} / \mathrm{m}^{2}$ の場合のように , 回転 数を増加していくと， $F_{\mathrm{a}}$ が頭打ちになる場合があるが， これは翼が失速するためと考えられる .

・第 4 6 図の $\eta$ が共通で $a$ が異なる結果を比較すると, 移 動板直径 $a$ を大きくすると，式 (6) で予想される以上に $F_{\mathrm{a}}$ が増加する .ケースと移動板のクリアランスが小さく なり，ヶース壁と移動板との干渉か強くなるためと考え られる。

-式 (6) から得られる予想とは違って, 第 7 図から分かる ように, 粘性係数 $\eta$ の増加によって $F_{\mathrm{a}}$ は線形に増加し ない．これは， $\eta$ の増加によって，壁での摩擦損失が大 きくなるためと考えられる .

・第 8 図から分かるように, 段数 $N$ による $F_{\mathrm{a}}$ の増加は式

(6) で予想されるほど大きくない . 段数か増えていくと， 後段翼への流入角が低下し，揚力係数が低下するためと 考えられる.

5.2 アクチュエータ減衰力 測定された抵抗力 $F_{\mathrm{d}}$ を， 変位 $=0$ でのアクチュエータの発生力 $F_{\mathrm{a}}$ と, 変位がある ための力 $F_{\varepsilon}$ との和とする .すなわち ，

$$
F_{\mathrm{d}}=F_{\mathrm{a}}+F_{\varepsilon}
$$

(ケース 1) の場合， $F_{\mathrm{d}}=8 N+F_{\varepsilon}$ であり，(ケース 2$)$ ， (ケース 3$)$ の場合， $F_{\mathrm{d}}=F_{\varepsilon}$ である .
○ Case1 $\square$ Case $2 \Delta$ Case 3

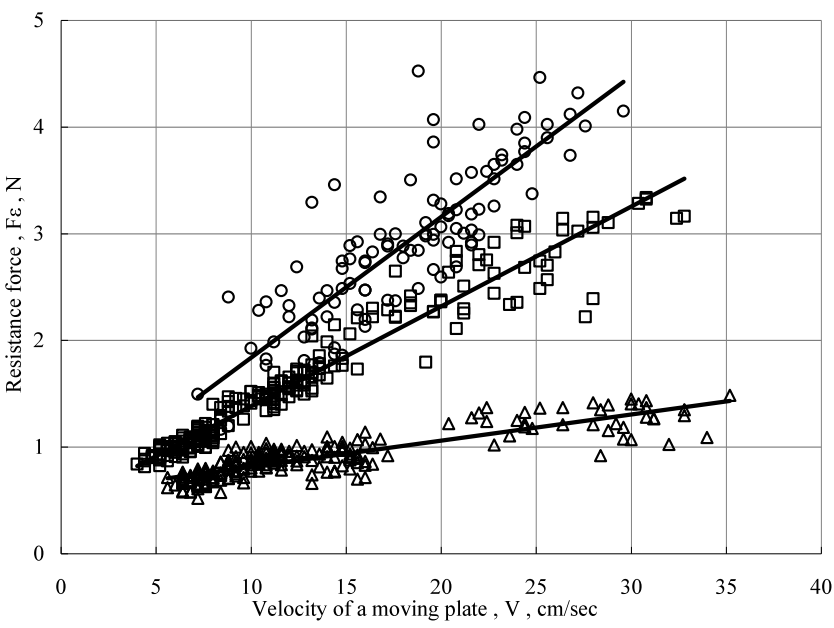

第9図 アクチュエータの減衰力

第 9 図に，変位速度 $V$ と $F_{\varepsilon}$ との関係を示す .この図か ら, $F_{\varepsilon}$ すなわち $F_{\mathrm{d}}$ と $V$ は線形関係があるので, 本アク チュエータは外力に対してダンパの機能を有している．ま た，ケース 1 と 2 との比較から， $F_{\varepsilon}$ は $F_{\mathrm{a}}$ によって増加す ることが分かる . ケース 3 は作動板がない場合の測定結果 であり，測定値には直動軸とケースとの間の摩擦，直動軸 に働く流体力が含まれる .ケース 1,2 の測定值にも，これ らの力が含まれている.ただし，ケース $1,2,3$ とでは, 流 れの樣子が異なるので, 直動軸に働く流体力は同一でない .

$$
\text { 6. ま と め }
$$

外力に対してダンパ機能を有する小型アクチュエータ を開発したが, 弚のアクチュエータではプロペラが $R e=$ 50 2 $210^{3}$ で作動する. 本レイノルズ数領域での翼特性 と, 高レイノルズ数で用いられる回転翼の性能評価法を合 わせることで, 本アクチュエータの発生力の大きさに影響 を与えるパラメータ (プロペラ回転数 , 使用流体の粘性係 数，作動円盤の直径等) を特定することができた . 低レイノ ルズ数での翼性能を明らかにすることで, 本アクチュエー タのようなプロペラを用いた小型流体機器の性能の理解が 可能になる .

本研究は, 堺工業技術研究会との共同研究として行われ たものである .

\section{参 考 文 献}

1) 得竹 浩, 砂田 茂: ダンパー機能付きアクチュエータと光の用 途，特願 2004-354374.

2) 倒れにくい自転車，日経ビジネス，2005 年 9 月 26 日号，日経 BP 社，東京，2005, pp. 112-114.

3) Muller, T. J.: Fixed and Flapping Wing Aerodynamics for Micro Air Vehicle Applications, AIAA, Virginia, 2001.

4) Gessow, A. and Myers, C. G.: Aerodynamics of the Helicopter, College Park Press, Bethesda, 1967.

5) Thom, A. and Swart, P.: The Forces on an Aerofoil at Very Low Speeds, J. Roy. Aero. Soc., 44 (1940), pp. 761-770.

6) Hoerner, S. F.: Fluid-Dynamic Drag, Published by the author, 1965. 